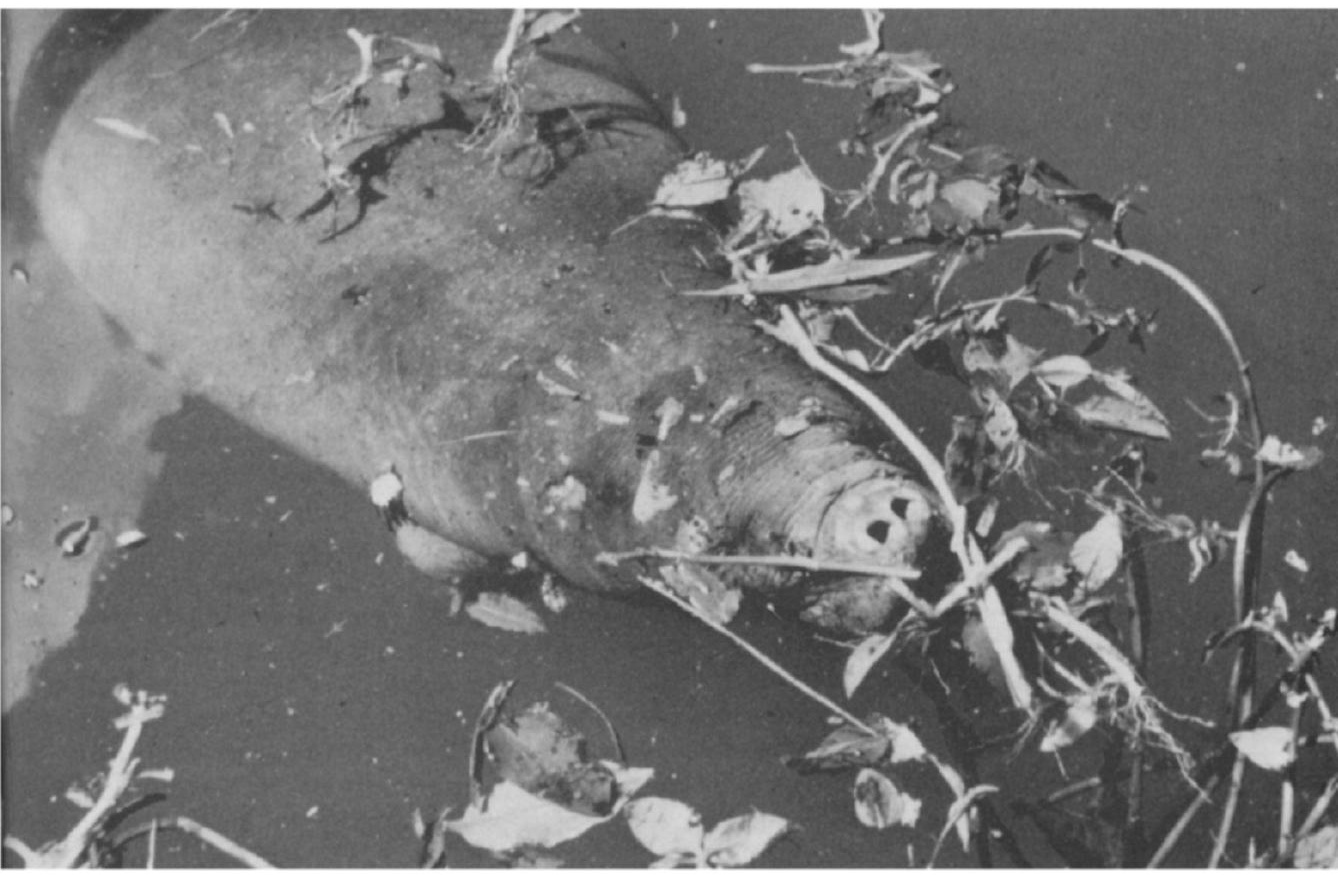

\title{
How to Save the Mermaids
}

\section{Sylvia Sikes}

'Seriously depleted throughout most of its range; needs to be brought under protective management', is the Red Data Book's verdict on the West African manatee Trichechus senegalensis. In Nigeria the author, who has worked there for many years, has only managed to see a few with great difficulty. She suggests the 'mermaid' is ideal for 'aquatic ranching', for the meat is so goodhence the species's depletion-that it is in great demand. The first need is to find out how many are left and where they are. But the manatee has none of the glamour of a tiger or a rhino; who, the author asks, would want to pay for the conservation of this unattractive but harmless and useful grazer of aquatic plants?

There are still a few mermaids to be found here and there in the delta creeks and lower reaches of the more sluggish West African rivers, but they are rarely seen except by fishermen and manatee hunters. I had spent many years in Nigeria before I saw my first living mermaid, and I only saw that one after enduring many long, cold, silent nights, motionless in dugout canoes, specifically listening and searching for them.

Now that I have slightly more experience of the species, I am sorry to say that I can see little in the appearance of the manatee to attract aesthetically. Floating idly just below the surface of the 


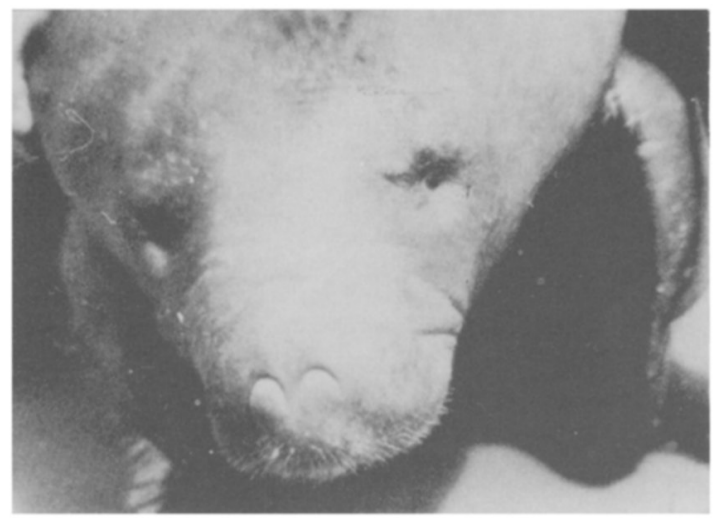

THE CAPTURED MANATEE, showing the small eyes, and nostrils closed during transit

water, maybe munching a water lily stem, the manatee looks to me disarmingly like a cross between a dirty barrage balloon and a grey maggot. Nevertheless, its curious serenity, the delicious idleness of its way of life, its utter harmlessness to man and beast, and the lotus-like simplicity of its diet (water lilies are its favourite food) seem to evoke in one a sense of timelessness-an empathy. It was therefore understandable, if a little surprising, that my rugged Australian colleague, on receiving our first captive mermaid could only gasp repeatedly, 'It's gorgeous, absolutely gorgeous!'

Of course our species, Trichechus senegalensis, like the American manatees and the dugong, is the subject of innumerable myths and legends. It is said (incorrectly) to have flowing tresses on its head-possibly trailing strands of green algae which sometimes grow on the head and back: certainly not long hair; that, as a culinary dish, its flesh has no equal; that its blubber, when rendered down, has both prophylactic and curative properties; and that the possession of certain parts of the body (notably the head and teeth) confers outstanding prowess in fields ranging from sport to politics, from sexual success to academic achievement. It is also said that the manatee has some 'human' attributes: pectoral mammary glands, the belly-to-belly posture during copulation, and the 'sigh'- the only sound audible above the water surface.

In Nigeria the manatee has been classified under the Wild Animals Law for many years as a 'prohibited' animal. However, thanks to its delicious flesh, its magical properties, and the widespread ignorance of its habits among the general public and law enforcement officers, hunting has continued unrestrained. Without exception, however, the professional fishermen and manatee hunters to whom I have spoken on the subject, are not only familiar with the animal, but also know that hunting it is illegal. They refer to it either by their own vernacular name for it, or in pidgin English as 'mammy-water' or as 'seal'. A too inquisitive government officer is told it is a seal, for 'seal' does not appear in the Wild Animals Law, neither do seals occur in Nigerian inland (or marine) waters. The author recently found a permit issued to a manatee hunter endorsed ' 20 seals'. 
HUNTER'S POSE to strike a manatee that comes to his grass bait

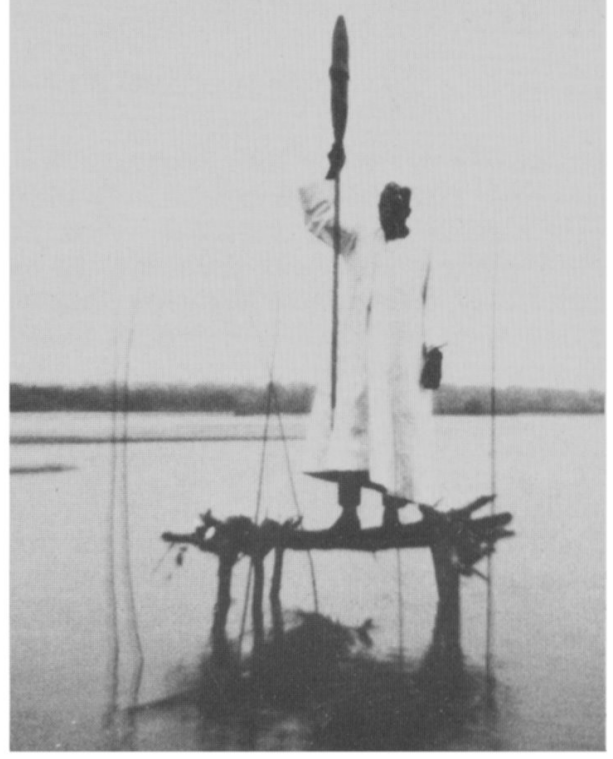

Within Nigeria there is evidence that manatees still occur in limited numbers in the Niger, Benue and Cross Rivers, their larger tributaries, and the delta creeks. Manatees cannot emerge at all on to land, nor can they clamber or leap up cataracts. They do not, and almost certainly never have, lived in Lake Chad or anywhere in the Chad Basin, as suggested in the new Red Data Book.

When I began my work on wildlife conservation for the government of Benue-Plateau State, Nigeria, I attempted to include a preliminary reconnaissance of the manatee herds in our rivers in a general wildlife survey. To do this, I accompanied a team of professional manatee hunters of the Kabawa tribe on several hunts. The Kabawa are Hausa people who originated in the north-western part of Nigeria and adopted a semi-nomadic way of life on the rivers as manatee hunters and fishermen. They usually have their permanent homes on the river banks, but spend the dry season camping in rush tents on sand banks in the river beds, following the fish and the manatees.

The Kabawa hunt manatees at night. They build a platform of forked sticks bound together with bark rope on a submerged sand bar close to deep water. Long whippy rods are arranged about a foot apart in the deep water in front of the platform, to form a screen. A bunch of freshly plucked green grass, of a species favoured by manatees, is tied loosely to the front of the platform, resting on the surface of the water. The hunter is armed with a single harpoon consisting of a strong, sharp, detachable head, with three or four barbs, loosely wedged at the lower end of a long, slender shaft. A strong nylon fishing line attaches the head to a palm float which rests on the top of the shaft, the remainder of the line being carefully wound on to pegs on the float. No poison is used.

At dusk the hunter takes up his position on his platform, sitting motionless and alone until, eventually, he may notice two of the rods being forced apart. He rises cautiously to his feet, waits until the 
manatee is munching the grass, and then strikes hard and deep into its back. The dorsal skin is usually more than $2 \frac{1}{2} \mathrm{~cm}$ thick, and is very hard and fibrous. With a cry of 'Praise God' he summons the other hunters who have been waiting nearby with the canoes, and away they go after the float. As they draw near, they play in the dying manatee, finish it off with a quick stab from a fishing spear, and tow it ashore for secret sale next day. It will fetch the equivalent of between $£ 120$ and $£ 300$ according to size.

As the Benue-Plateau State Wildlife Conservation Programme took shape, it seemed wise to try to capture and translocate some manatees to safer areas, both for further study, and to see if they could be conditioned to the human presence sufficiently to show them to the public. This seemed to be the best way to attract public interest to make the conservation of the species worthwhile, as well as to further law enforcement.

The Fauna Preservation Society generously drew on its Oryx $100 \%$ Fund to enable us to purchase an outboard engine for our boat and to complete the construction of the translocation apparatus. In March 1973, my colleagues and I began our first safari to attempt to capture a living mermaid. We spent six wearying weeks on the Katsina-Ala River, a large tributary of the Benue, working with a family of manatee hunters who knew the river well, and in that period only one manatee came to our bait. Night after night we sat up on mosquito-infested sand banks and day after day we travelled the river making enquiries and searching for signs. It became quite clear to us that manatees were already very scarce indeed in the Katsina-Ala River.

I was also beginning to realise just how difficult it is for many leading Nigerians, whose childhood homes were in the Benue Valley, but who subsequently trained and began their careers elsewhere, to appreciate the degree to which the wildlife in the valley has decreased in the past ten to fifteen years. In this period of rapid development, environmental reaction to the inroads made on wilderness areas by settlements and farms, and the effect of the everextending use of nylon nets in the rivers and lakes, has far exceeded that anticipated. Although the true situation is clear to a few, and they have done everything in their power to encourage the work of the Wildlife Unit, there are others who flatly refused to believe in the wildlife decline, and not only belittled but deliberately resisted our work. When one very senior government official kindly offered to find me a good hunter who would show me the 'many manatees' he remembered in his youth in the Farin Ruwa River, he was surprised by the hunter's reply: 'Manatees are now too few to find'.

A few days after we left our last camp on the Katsina-Ala River, some fishermen unintentionally and quite unexpectedly caught a young 2-metre male manatee in their fishing net in the Benue River. Our lorry driver and head game guard, with their team, were returning home in the lorry with the translocation equipment, when they heard this news, and they carefully loaded and brought the manatee the 90 -odd miles to Lake Pandam, a small natural lake in the newly gazetted, 120-square-mile Pandam Wildlife Park. There 
my colleague kept it for two weeks and then brought it the further 200 miles to the Wildlife Unit Headquarters at Jos, where there is a double swimming pool now grandly known as The Manatarium. Although this is seven miles from the centre of Jos, the State capital, several hundred people came to see the manatee during the five weeks before it died from injuries received during capture.*

\section{First Steps}

We learnt a great deal from our first captive mermaid, both through direct observation and contact and from many of the Nigerian visitors who came to see it. So little is as yet known scientifically about the West African species that it is difficult to make realistic long-term proposals for its conservation. Any comprehensive conservation programme would be extremely difficult and expensive to carry out due to the difficult terrain and to the political instability of so many of the nations and states concerned.

My own view is that the initial step should certainly be a comprehensive survey of manatee distribution throughout West Africa by a suitably equipped international team of sirenian specialists. An added incentive to such a survey would be the fact that it would also incidentally reveal any surviving populations of the pygmy hippopotamus which had been overlooked up to the present time, as the range of that species lies within that of the manatee and in the same habitat.

During the progress of such a survey it would become apparent which States were willing and suitable for further participation, being assessed not only by the possession of accessible manatee populations for direct and immediate protection or for translocation, but also by the effectiveness of their existing wildlife conservation programmes.

It is my belief that the most effective way to conserve the species is by aquatic ranching either in suitable natural lakes or in specially constructed artificial ones. The idea is not new, but, whereas in the past it has only been considered incidentally to proposed weed clearance schemes, it is here suggested as an end in itself, like a fish farm, for example.

The requirement would be for a natural lake, rather long and narrow in shape, or, alternatively a series of long, narrow artificial lakes, supplied by an unpolluted source of natural perennial water, providing a steady through flow towards a guarded outlet. Each lake would need to have both deep and shallow, shaded and sunny, weedy and clear areas. Each would need to have a marshy area with marsh grasses growing in shallows suitable for manatee grazing and breeding, as well as deeper pools below steep banks where the animals could be observed while at rest. Each lake would have to be adequately stocked with water lilies and fodder weeds favoured by

\footnotetext{
* In April this year Dr Sikes reported that two more live manatees, a male and a female, captured by fishermen, are now at Jos- better than the only alternative fate of being eaten'. It is hoped to release them in October in the fully protected Pandam Wildlife Park. Editor
} 
the manatees, and would have to be large enough to allow the animals to do their own territorial zoning yet small enough to allow for management and recapture.

It is believed that each cow gives birth annually to a single calf and that maturity may be reached at about seven years of age. Manatees are believed to live about thirty years, and to attain a weight of about $500 \mathrm{~kg}$ at maturity, so a successful manatee ranch could prove very productive. If the ecosystem were managed specifically to provide optimum conditions for manatee breeding and growth, a realistic objective for each manatee ranch would be to produce sufficient stock for relocation and/or harvesting and marketing. Moreover, it has already been demonstrated that in captivity manatees readily accept the human presence and are responsive to 'training' with the voice and by means of whistles, so it should eventually be possible also to open at least a portion of each manatee ranch to tourists and students.

It may be argued that none of the attempts made up to the present time to stock dams and irrigation channels with American manatees for weed clearance purposes has resulted in successful breeding, and therefore this proposal cannot seriously be expected to work. However, there is reason to believe that the dams and channels into which the manatees were introduced were either unsuitable in physical shape or capacity to permit breeding, or they were so large that the results could not be monitored. In our programme in BenuePlateau State, we hope in the near future to be able to observe breeding in natural conditions and to see for ourselves what those conditions really are.

We still know very little about 'mammy-water'-its nutritional, territorial, social and migratory requirements. We know practically nothing about its communicatory and sensory mechanisms, underwater 'language', and population dynamics. Its love life, too, would make a fascinating study. Surely conservationists can do something to prevent it from joining, like Steller's sea-cow, the ranks of the culinarily delicious, but scientifically unknown, extinct species.

\section{A Difficult Challenge}

The West African manatee presents an exceedingly difficult, unattractive and expensive challenge to the conservationist for not only is it not beautiful, but it is difficult to see and catch, and its habitat is shared with the vicious vectors of several debilitating, and some fatal, fevers, as well as of bilharzia and river blindness, and characterised by treacherous river currents, slime-covered mud banks, crocodiles and electric fish. It is glamorous to conserve tigers and giant pandas, elegant to conserve oryx and okapi, exciting to conserve grizzly bears and rhinos, fashionable to conserve cheetahs and orang utans. Even the Loch Ness monster-if ever identified-is now in the queue of applicant subjects for conservation. But the mammy-water ...?

Dr Sikes is Consultant Zoologist (Wildlife) to the Ministry of Natural Resources in the Benue Plateau State, Nigeria. 